\title{
Case of Cystic Graffian Follicles in Cattle
}

\author{
Shambhavi*, Harshit Saroha, Aditya Kumar and Shubham Kumar \\ Veterinary Gynaecology and Obstetrics, University/Organization, India \\ *Corresponding Author: Shambhavi, Veterinary Gynaecology and Obstetrics, \\ University/Organization, India.
}

Received: : December 13, 2021

Published: January 31, 2022

(C) All rights are reserved by Shambhavi., et

al.

\section{Abstract}

Follicular cyst is an ovarian dysfunction resulting in reproductive failure in dairy cattle. It is recognized as enlarged anovulatory follicle like structures $(<2.5 \mathrm{~cm})$ and persisting for 10 or more days in dairy cows. Accurate diagnosis of follicular cyst currently employs a combination of transrectal palpation, transrectal ultrasonography and plasma progesterone assay. In field conditions the manual rupture of follicle was generally advocated, yet during the past several years single or combined use of GnRH, progesterone and prostaglandins have been in clinical practice. Other therapies include estrogen receptor blocker clomiphene citrate and transvaginal ultrasound guided cystic follicle aspiration. Homeopathic medications for the follicular cyst have also come in trend but success of therapy is governed by many confounding variables such as persistence of the follicles and duration of the pathological condition. The correct choice of treatment and implementation of the preventive measures can help in reducing economic loss caused by the disease to the dairy industries.

Keywords: Cystic Ovarian Degeneration; Follicular Cyst; Hormonal Assay; Progesterone Implants Homeopathic Medication; GnRH

\section{Introduction}

The disease Cystic ovarian degeneration was first described in 1831. This is also called 'cystic ovarian disease', 'cystic Graffian follicles', 'Ovarian cysts', 'luteal ovarian cysts, and 'cystic cows' [13] This is the condition in which follicle-like ovarian structures that are $2.5 \mathrm{~cm}$ in diameter or larger and persist for 10 days or more generally in the absence of corpus luteum [15]. Ovaries are said to be cystic when they contain one or more fluid-filled structures larger than a mature follicle $(>2.5 \mathrm{~cm}$. in diameter), which persist for more than 10 days and result in aberrant reproductive function [30].

\section{Etiology}

This condition has various causes which include hereditary predisposition [7], age, nutritional disbalance, season, stress, endocrine imbalance [11], and postpartum uterine infections [8].
The incidence is higher in that lactation in which milk yield is at peak [28]. Therefore, an ovarian cyst is uncommon in the first lactation. Feeding of high protein diets causes a higher incidence of the disease. Diseases like ketosis, dystocia, twin births, retention of fetal membrane, milk fever [23]. The factors inducing stress which initiates the release of ACTH suppressing LH secretion are also responsible for the occurrence of the disease in cattle [29]. The uterine infections caused by microorganisms are often responsible for cystic ovarian degeneration which produces endotoxin in the uterus that triggers the PGF2 $\alpha$ release, which stimulates the secretion of cortisol. The elevated cortisol level suppresses the preovulatory release of $\mathrm{LH}$ and leads to the development of cysts.

Cystic ovarian degeneration can be classified in two forms according to their nature of occurrence: Follicular cysts and Luteal cysts. 


\section{Follicular cysts}

The case presented was observed to be of follicular cyst in which a thin-walled anovulatory follicle was observed on the ovary for 10 days with a diameter of $2.5 \mathrm{~cm}$ and more. the case was characterized by nymphomania [15]. Nymphomania is the condition in which there is either a short interval between two consecutive estrus cycles or the animal displays excessive and prolonged signs of estrus [41]. Presence of sexual aggressiveness like a bull in the affected cow, "Buller cow syndrome". Follicular cysts are multiple and are present on one or both ovaries [40]. The follicular cyst was found to be distended with the smooth convex surface with fluctuating fluid-filled feeling on palpation. The fluid-filled inside the cyst was pale yellow or straw-colored. Signs reported by the owner were attempts to ride other cows and to be mounted by other cows. The mucus was tougher and opaquer than the mucus of estrus and there are no leucocytes in mucus when observed under a microscope. External os of the cervix was usually large, dilated, and relaxed.

In long-standing cases of nymphomania, the relaxation of pelvic ligaments causes tipping of the pelvis and elevation of the tail-head [41]. The elevated tail head is called a sterility hump. In many cases, this hump persists after recovery from the disease as ligaments fail to regain their tone [41]. Hydrometra or mucometra is also found in long-standing cases of follicular cysts. In a few cases, cystic dilatation of the endometrial glands occurs developing a Swiss-cheese appearance on the histological section [1]. Though none of these signs was observed in the present case.

\section{Diagnosis}

Acquiring full history of the disease from the owner and observing signs and symptoms.

\section{Behavioral changes}

The most common condition is found to be anestrus [14], especially during the postpartum period [20]. Also, the development of masculine physical traits and irregular estrus intervals during lactation could be observed to determine the chances of the cysts $[35,42]$. Due to the anovulatory nature of the follicular cysts, determination of the nymphomaniac and irregular cycles can also be considered as the suspected condition of the ovarian cyst [19]. Erratic milk production along with raised tail-head is considered as a key sign of the disease [41].
Clinical examination via rectal palpation. Observe the ovary and differentiate with normal follicles accordingly.

A normal preovulatory follicle may approach $2.5 \mathrm{~cm}$. in diameter. Its palpable characteristics of being a thin-walled, fluid-filled, smooth structure raised above the surface of the ovary may be confused with the follicular cyst. For this, see the changes in uterus palpation and its symptoms. Before confirming the cyst, it is recommended to wait for one 1-month post-calving before attempting to diagnose cystic ovarian degeneration. Then $2^{\text {nd }}$-time palpation should be done within 7-10 days if possible and retreated if necessary.

Transrectal ultrasound imaging [12].

\section{Hormonal determination}

Plasma or milk progesterone levels vary according to the type of cyst. In follicular cyst the progesterone concentration is $\leq 2 \mathrm{ng}$ / $\mathrm{ml}$ [19]. Progesterone levels were determined by using a bench-top assay kit [4].

All techniques mentioned were used for the diagnosis of follicular cyst in the case presented.

\section{Treatment}

Various approaches are used for the treatment of follicular cyst

- Manual rupture: Manual rupture of cystic structures can be done by rectal palpation [41]. Ovarian hemorrhages and adhesions may follow manual rupture, which could further cause infertility. Therefore, manual rupture should be discouraged $[9,36]$.

- Gonadotropin-releasing hormone (GnRH): After treatment with GnRH analogue (Buserelin), most of the cows that respond come in estrus 18 to 23 days after treatment. Receptal (Buserelin) - $5 \mathrm{ml}$ (intramuscular route). Some cows that failed to respond to GnRH treatment or with recurrent cysts can be given a second dose of GnRH [24]. Lecirelin (a GnRH analogue) shows the remission of the follicular cysts and enhances the reproductive parameters when administrated epidurally [3] and $0.1 \mathrm{mg}$ intramuscularly in cows [37].

- Progesterone and its implants: It's found that exogenous administration of progesterone may disrupt the endocrine environment that is required to maintain the follicular cysts 
by exerting strong negative feedback on LH plus frequency [21] which reduce LH in cows with cysts leading to regress the cysts and develop normal ovulatory follicles [6]. chronic along with acute treatment of progesterone on day 9-14 caused a rapid reduction in the size of follicle cysts $[2,17,27]$. CIDR was found to be the most effective implant of progesterone in restoring ovulation and reoccurring of the normal cyclicity in the beef donor cows which were affected by persistent cysts for a long period [10].

- $\quad$ Sequential GnRH and PGF2 $\alpha$ treatment: Ovarian cysts that luteinize in response to GnRH administration undergo regression similar to that of normal corpora lutea. The luteolytic activity of PGF2 $\alpha$ reduces interval from the treatment with GnRH to the first estrus (18 to 23 days). PGF2 $\alpha$ should be given on the 9th day, after GnRH treatment. 0th-day Receptal ( $5 \mathrm{ml}$ - intramuscular route) followed by 9 th-day Lutalyse ( 5 ml- intramuscular route) followed by $11^{\text {th }}$ day Double artificial insemination this treatment results in successful conception. The efficacy of GnRH therapy along with PGF $2 \alpha$ at the rate of $0.5 \mathrm{mg}$ and $20 \mathrm{mg}$ after 9 days (post-GnRH injection) was found to be about $91.66 \%$ [25].

- Clomiphene citrate: An estrogen antagonist, believed to exert direct action on the endocrine glands to stop the production of the estrogen-induced LH release [38]. An oral administration of Clomiphene citrate at the rate of $300 \mathrm{mg}$ after drenching 1\% copper sulphate has been suggested for the treatment of ovarian cysts [39].

- Homoeopathic drugs: Apis (for the right-side ovarian cyst) and Lachesis (for the left side ovarian cyst) twice daily for 5 days immediately followed by Natrummur twice daily for 3 days show results to cure ovarian cysts [18].

- Needle aspiration: A better alternative to manual rupturing of the cysts is single transvaginal-guided needle aspiration of ovarian follicular cysts [22]. The limitation of this technique arrives with the chances of regeneration of cysts or mucometra [33]. These conditions now can be cured by administration of $3-10 \mathrm{gm}$ of potassium iodide for 5 - 10 days orally $[5,32,34]$ or by administration of elemental iodide parentally [26] or by uterine lavage $[16,32]$.

\section{Conclusion}

Cystic follicles are the major cause of reproductive insufficiency in dairy cattle. Generally, 5 - 10\% of cows are affected with COD per year but the incidence may go up to $30 \%$. This disease results in prolonged calving intervals by 40 - 50 days more than the nonaffected cows. Cows become infertile as long as the condition persists. It increases days open in the postpartum period and the calving rate as a consequence of a mature follicle that fails to ovulate at the time of ovulation in the estrous cycle. The disease is not very frequently diagnosed in the field and the treatment used is generally manual rupture which increases the extent of damage leaving animal infertile.

As we can see there aren't many preventive measures that can be followed for avoiding cystic ovarian degeneration, but selective breeding and post-partum GnRH treatment can reduce the incidence of ovarian cyst.

\section{Bibliography}

1. Al-Dahash SY and David JS. "Histological examination of ovaries and uteri from cows with cystic ovaries". Veterinary Record 101.17 (1977): 342-347.

2. Anderson LH and Day ML. "1994 Acute progesterone administration regresses persistent dominant follicles and improves fertility of cattle in which estrus was synchronized with melengestrol acetate". Journal of Animal Science 72.11 (1994): 2955-2961.

3. Annalisa R., et al. "Epidural vs intramuscular administration of lecirelin, a GnRH analogue, for the resolution of follicular cysts in dairy cows". Animal Reproduction Science 126 (2011): 19-22.

4. Bartolome JA., et al. "Strategies for the diagnosis and treatment of ovarian cysts in dairy cattle Journal of the American Veterinary Medical Association 227 (2005): 1409-1414.

5. Bugalia NS and Kohli IS. "Comparative efficacy of proluton depot, gonadotropin-LH and potassium iodide in nymphomaniac Rathi cows". Haryana Agricultural University Journal of Research 11 (1981): 575-577.

6. Calder MD., et al. "Administration of progesterone to cows with ovarian follicular cysts results in a reduction in mean LH and LH pulse frequency and initiates ovulatory follicullar growth". Journal of Animal Science 77 (1999): 3037-3042.

7. Dawson FLM. "Bovine Cystic Ovarian Disease-A review of recent Progress". British Veterinary Journal 113 (1957): 112-133.

8. Dawson FLM. "Bovine Cystic Ovarian Disease: An Analysis of 48 Cases Article 2". British Veterinary Journal 114 (1958): 96105. 
9. Dobson H., et al. "Bovine cystic ovarian disease: plasma hormone concentrations and treatment". Veterinary Record 101 (1977): 459-461.

10. Douthwaite R and Dobson H. "Comparison of different methods of diagnosis of cystic ovarian disease in cattle and an assessment of its treatment with a progesterone-releasing intravaginal device". Veterinary Record 147 (2000): 355-359.

11. Eyestone WH and RL AX. "A Review of Ovarian Follicular Cysts in Cows, With Comparisons to the Condition in Women, Rats and Rabbits". Theriogenology 22 (1984): 109-125.

12. Farin PW., et al. "Diagnosis of luteal and follicular ovarian cysts in dairy cows by sector scan ultrasonography". Theriogenology 34 (1990): 633-642.

13. Garverick HA. "Ovarian follicular cysts in dairy cows". Journal of Dairy Science 80 (1997): 995-1004.

14. Garverick HA. "Ovarian Follicular Dynamics and Endocrine Profiles in Cows with Ovarian Follicular Cysts". In: J. L. Howard and R. A. Smith (Eds.) Current Veterinary Therapy 4: Food Animal Practice W.B. Saunders Company, Philadelphia (1999) 577-580.

15. Hamilton SA., et al. "Characterization of ovarian follicular cysts and associated endocrine profiles in dairy cows". Biology Reproduction 53 (1995): 890-898.

16. Jeengar K., et al. "Ovarian cysts in dairy cows: old and new concepts for definition, diagnosis and therapy". Animal Reproduction (AR) 11.2 (2018): 63-73.

17. Johnson A and Ulberg L. "Influence of exogenous progesterone on follicular cysts in dairy cattle". Journal of Dairy Science 50 (1967): 758-761.

18. Karreman HJ. "Ovarian cysts. In: Karreman HJ”. Treating Dairy Cows Naturally: Thoughts and Strategies. Austin, TX: Paradise Publications (2007): 291-292.

19. Kasari R., et al. "Bovine COD and the role norgestomet can play in its treatment". Veterinary medicine 91 (1996): 156-162.

20. Kesler DJ and Garverick HA. "Ovarian cysts in dairy cattle: a review”. Journal of Animal Science 55 (1982): 1147-1159.

21. Kinder J., et al. "Progestin and estrogen regulation of pulsatile LH release and development of persistent ovarian follicles in cattle". Journal of Animal Science 74 (1996): 1424-1440.
22. Lievaart JJ., et al. "Transvaginal aspiration as first treatment of ovarian follicular cysts in dairy cattle under field circumstances". Tijdschr Diergeneeskd 131 (2006): 438-442.

23. Lopez-Gatius F., et al. "Risk factors for postpartum ovarian cysts and their spontaneous recovery or persistence in lactating dairy cows". Theriogenology 58 (2002): 1623-1632.

24. Lopez-Gatius F and Lopez-Bejar M. "Reproductive performance of dairy cows with ovarian cysts after different GnRH and cloprostenol treatments". Theriogenology 58 (2002): 1337-1348.

25. Majeed AF and Ali JB. "Treatment of follicular cystic ovaries in dairy cattle". Indian Veterinary Journal 64 (1987): 340-342.

26. McDonald RJ., et al. "The use of organic iodine in the treatment of repeat breeder cows". In: Proceedings of the IV International Congress on Animal Reproduction, The Hague, 1961. The Hague: ICAR (1961): 679-681.

27. McDowell C., et al. "Duration of treatment with progesterone and regression of persistent ovarian follicles in cattle". Journal of Animal Science 76 (1998): 850-855.

28. Nelson ST., et al. "Risk factors associated with cystic ovarian disease in Norwegian dairy cattle". Acta Veterinaria Scandinavica 52 (2010): 60.

29. Ortega HH., et al. "Molecular aspects of bovine cystic ovarian disease pathogenesis". Reproduction 149.6 (2015).

30. Peter AT. "Infertility due to abnormalities of the ovaries". In: Youngquist, RS (ed.), Current Therapy in Large Animal Theriogenology. WB Saunders, Philadelphia (1997)349-354.

31. Prasithiphol S., et al. "Uterine flushing in repeat breeding dairy cows using normal saline and antibiotic solution". Thai Journal of Veterinary Medicine 29 (1999): 33-43.

32. Purohit GN., et al. "Cystic ovarian disease in Rathi Cattle". Annals of Arid Zone 40 (2001): 199-202.

33. Purohit GN. "Recent developments in the diagnosis and therapy of repeat breeding cows and buffaloes". CAB Reviews Perspectives in Agriculture Veterinary Science Nutrition and Natural Resources 3.62 (2008): 1-34.

34. Rajan A., et al. "Efficacy of iodine supplementation in cows with anoestrum and repeat breeding". Journal of Veterinary and Animal Sciences 22 (1991): 119-121. 
35. Roberts SJ. "Veterinary Obstetrics and Genital Diseases (Theriogenology). 2nd ed. Ann Arbor, MI: Edward Brothers (1971): 421-435.

36. Roberts SJ. "Hormonal Disturbances resulting in Infertility". In: S. J. Roberts (Ed.) Veterinary Obstetrics and Genital Diseases (Theriogenology) (1986): 478-494.

37. Silva AM., et al. "Treatment of ovarian cysts in cattle with lecirelin acetate". Animal Reproduction 9 (2012): 591.

38. Terakawa N., et al. "A possible role of clomiphene citrate in the control of preovulatory LH surge during induction of ovulation". Acta Endocrinology (Copenhagen) 109 (1985): 58-63.

39. Thakur MS., et al. "Efficacy of fertivet (clomiphene) on cystic ovaries in crossbred Holstein Friesian and Haryana cows". Cheiron 12 (1983): 263-264.

40. Vanholder T., et al. "Aetiology and pathogenesis of cystic ovarian follicles in dairy cattle: a review". Reproduction Nutrition Development 46 (2006): 105-119.

41. Williams WL and WW Williams. "Nymphomania of the CowCase Reports". The North American Veterinarian 4 (1923): 305-315.

42. Youngquist RS. "Cystic follicular degeneration in the cow". In: Morrow DA (Ed.). Current Therapy in Theriogenology. 2nd ed. Philadelphia: WB Saunders (1986): 243-246.

\section{Assets from publication with us}

- Prompt Acknowledgement after receiving the article

- Thorough Double blinded peer review

- Rapid Publication

- Issue of Publication Certificate

- High visibility of your Published work

Website: www.actascientific.com/

Submit Article: www.actascientific.com/submission.php

Email us: editor@actascientific.com

Contact us: +919182824667 